\title{
COMPARISON OF SUPERMARKET AND TRADITIONAL MARKET SUPPLY VEGETABLE FARMERS OF TWO DISTRICTS OF INDIA
}

\author{
Aparna ${ }^{1}$ \\ Contract teaching faculty, Dept of Veterinary \& A.H Extension, NTR College of Veterinary \\ Science, Gannavaram, Andhra Pradesh, India
}

\begin{abstract}
The study was done on the economic analysis of tomato, brinjal and bhendi cultivation with a comparison of income, access to technology of supermarket and traditional market supply farmers in the two selected districts. The per hectare cost of cultivation of the three selected vegetables on supermarket and traditional market supply farms revealed that cost of cultivation of vegetables was remarkably higher for traditional farms than supermarket supplying farms. This was mainly due to excessive use of manures and fertilizers, irrigation, plant protection chemicals and human labour. The returns per rupee invested have been noted higher for supermarket supply farmers than that of traditional farmers. The evidence indicates that innovative institutions contribute in reducing production cost and augmenting farm profits. Discriminant function analysis shows that price, manures and fertilizers, yield, hired labour and net income contributed mostly to discriminate between two groups' viz., supermarket and traditional market supplying farmers.
\end{abstract}

Key words: Andhra pradesh, marketing of vegetables, supermarket supply channel; traditional market supply channel.

\section{INTRODUCTION}

Indian agriculture is gradually diversifying towards high-value food commodities. This is expected to benefit millions of farmers especially smallholders, who rely on agriculture for their livelihood. The challenges that supermarkets pose in certain circumstances on small producers may have a comparative advantage over larger commercial growers (David et al., 2003). Vegetables are considered as protective food and acts as a regular source of returns in farm business. Production of vegetables is limited to a small proportion of farmers because of high production and

\footnotetext{
${ }^{1}$ Corresponding author email: draparnaeco@gmail.com,cvh555@gmail.com
} 
market risks, institutional linkages between production and markets enable farmers to cope with such risks, contribute to more efficient markets and extension, and reduce public institution costs. Agribusiness firms enhanced skills and provided training in clean production, and provided inputs, technology, credit, and services to improve competitiveness. Demand for vegetables in India is income-elastic and is expected to grow faster as the factors underlying demand growth that is income growth and urbanization, have been quite robust during this period and are unlikely to subside in the near future. In other words, rapid growth in demand for high value food commodities opens up immense income and employment opportunities for producers especially, small holders and other stakeholders as the cultivation of vegetables is more profitable, capital and labour intensive compared to staples and other cash crops. This offers a perfect opportunity to small holders to augment their income and employment. Evidence from many Asian and African countries indicates that vegetable production requires 1.5-3 times more labour and generates 1.3-14 times more returns compared to cereals (Joshi et al., 2006). The farmers connected to organised retail in India have larger land holdings (Joseph et al., 2008; Mangala and Chengappa, 2008; Alam and Verma, 2007) and higher proportion of irrigated land (Joseph et al., 2008) than those supplying to traditional market channels. Studies on fresh fruit and vegetable retail chains in India have confirmed relative advantages for farmers connected with organised retail and the farmers contracted by retail chains received comparatively higher prices (Dhananjaya and Rao, 2009).

For supplying to supermarket less perishable commodities are procured from the farmers by setting up collection centers in the niche production regions. Most organised food retail ventures are involved in arrangements of procurement without any contracts or commitments, apart from paying farmers at price for the produce (Sulaiman et al., 2010). The procurement officers provide technical support to the member farmers in preparation and planning of crop calendar and showing schedules to get the desired supply on a regular basis. For other inputs, the firm maintains a panel of some reputed input dealers and recommends producers to source their requirements from them. Producers, however, are free to buy from anywhere. In general, input price charged by these dealers are marginally less than their market prices. Extension services such as selection of quality inputs, sowing techniques, irrigation management practices, identification of pests and diseases and their management, harvesting techniques, and grading, standardization and packaging methods are provided to the farmers at free of cost to farmer. Singh (2010) report that retail chains have raised quality consciousness among farmers introduced grading (in primary processing) and have helped cost-cutting through extension and training on input use for better yield.

Under this perspective, the present study is undertaken with the following objectives: (i) to analyse the economics of vegetable production of supermarket and traditional market supply farmers, (ii) to compare the income of these two groups of 
farmers, and (iii) to specify the variables that are discriminating the supermarket supply farmers from traditional market supply farmers.

\section{MATERIALS AND METHODS}

Medak and Rangareddy Districts of Andhra Pradesh were purposively selected for the present study as they were supplying vegetables to many corporate retail companies like Reliance Fresh, More, Spencers, ITC e-choupal which were operating their retail outlets in Hyderabad city. The study focuses on three fresh vegetables namely tomato, brinjal and bhendi as they are farmer perspective (regularly providing income for producers). A total of 468 vegetable cultivators were selected of which 234 are from Rangareddy district and 234 are from Medak district. Among the 234 farmers, 117 farmers are linked with supermarkets and 117 farmers are supplying vegetables to traditional markets. Out of 117 farmers 39 each of tomato, brinjal and bhendi farmers were selected randomly taking two categories of farmers i.e. small and large from each district.

Primary data on cost of cultivation of both the group of farmers was collected during the year 2009-2010 through a pre-tested schedule. Analysis was done to estimate costs according to cost concepts where income measures and Discriminant function were employed as shown below.

\section{Cost concepts:}

Cost $\mathrm{A}_{1}$ : All the variable costs excluding family labour cost and including interest on working capital; Cost $\mathrm{A}_{2}$ : Cost $\mathrm{A}_{1}+$ rent paid for leased-in land; Cost $\mathrm{B}_{1}$ : Cost $\mathrm{A}_{1}+$ interest on value of owned capital assets (excluding land); Cost $\mathrm{B}_{2}$ : Cost $\mathrm{B}_{1}$ + rental value of owned land + rent paid for leased- in land (net of land revenue); Cost $\mathrm{C}_{1}$ : Cost $\mathrm{B}_{1}+$ imputed value of Family Labour; Cost $\mathrm{C}_{2}$ : Cost $\mathrm{B}_{2}+$ imputed value of Family Labour and Cost $\mathrm{C}_{3}: 10 \%$ of $\mathrm{C}_{2}$.

\section{Income measures:}

Gross income: Yield of the crop $\mathrm{X}$ market price received per quintal; Net income : Gross income - Cost $\mathrm{C}_{2}$; Farm business income : Gross income - Cost $\mathrm{A}_{1}$ or Cost $\mathrm{A}_{2}$; Family labour income : Gross income - Cost $\mathrm{B}_{2}$; Farm investment income : Farm business income - imputed value of family labour.

\section{Discriminant Function}

Discriminant functional analysis was used to know the relative importance of different variables, power of relevant variables to discriminate between two groups of farmers viz., suppliers to supermarkets and non- supplier to supermarkets. The discriminant function employed was of the following form:

$\mathrm{p}$

$$
\mathrm{Z}_{1}=\sum_{\mathrm{i}=1} \mathrm{~L}_{\mathrm{i}} \mathrm{X}_{\mathrm{i}} \quad \text { (for first group farmers ) }
$$




$$
Z_{2}=\sum_{i=1}^{p} L_{i} X_{i} \quad \text { (for second group farmers ) }
$$

Where, $\mathrm{Z}=$ Total discriminant score for both group of farmers, $\mathrm{X}_{\mathrm{i}}=$ Variables selected to discriminate the two groups; and $\mathrm{L}_{\mathrm{i}}=$ Discriminant coefficients of the variables estimated from the data.

\section{$\mathbf{S} \mathbf{L}=\mathbf{d}$}

Where,

$\mathrm{L}=$ Column vector of the coefficient of discriminant function, $\mathrm{S}=$ Pooled dispersion matrix $S_{i j}$ (pooled covariance matrix of the same groups), $d=d_{1}$, $\mathrm{d}_{2}, \ldots \ldots \ldots \ldots \mathrm{d}_{\mathrm{p}}$ was the vector of mean differences on the ' $\mathrm{p}$ ' original measure.

The discriminant function was tested for significance, whether the variables considered together were significantly discriminating between the two groups. Mahalanobis $\mathrm{D}^{2}$ statistics was used to measure the discriminating distance between the two groups as follows:

$$
\begin{array}{rll}
\quad \mathrm{p} & \mathrm{n} & \mathrm{n} \\
\mathrm{D}^{2}{ }_{\mathrm{ab}}=(\mathrm{n}-\mathrm{g}) \sum & \sum \mathrm{W}_{\mathrm{ij}}\left(\mathrm{X}_{\mathrm{ia}}-\mathrm{X}_{\mathrm{ib}}\right)\left(\mathrm{X}_{\mathrm{ja}}-\mathrm{X}_{\mathrm{jb}}\right)=\sum \mathrm{L}_{\mathrm{i}} \mathrm{d}_{\mathrm{i}}
\end{array}
$$

Where, $\mathrm{n}=$ total number of cases, $\mathrm{g}=$ number of groups, $\mathrm{p}=$ number of variables, $X_{i a}=$ Mean of $i^{\text {th }}$ variable in group ' $a$ ', $W_{i j}=$ Element from the inverse of within groups covariance matrix; and $\mathrm{L}_{\mathrm{i}}=$ Inverted matrix of the coefficients of the discriminant function. $\mathrm{a}=$ suppliers, $\quad \mathrm{b}=$ non suppliers. The significance of $\mathrm{D}^{2}$ as tested by applying the following F- test. $\mathrm{D}^{2}=\left(\mathrm{X}_{1}-\mathrm{X}_{2}\right) \mathrm{S}^{-1}\left(\mathrm{X}_{1}-\mathrm{X}_{2}\right)$; and $\mathrm{S}=$ Pooled covariance matrix of the two samples.

\section{RESULTS AND DISCUSSION}

\section{Cost of cultivation of vegetables}

Various components of cost of cultivation of tomato, brinjal and bhendi farmers for supermarket and traditional market supply in Rangareddy and Medak districts were presented in tables-1,2,3. In Rangareddy district, operational cost per hectare was less for supermarket supply tomato small farmers (Rs. 18978) over traditional market supply tomato farmers (Rs. 21589) due to excess indiscriminate usage of seeds, manures and fertilizers and plant protection chemicals (Table 1). Among the operational costs for tomato of small farmers, human labour occupies a major share (28.38 and 30.20) of total cost of (Rs. 36379 and Rs. 38855) of supermarket and traditional market supply, respectively. In Medak district also the operational cost per hectare was less for supermarket supply farmers (Rs. 19206) over traditional market supply tomato farmers (Rs. 20825). Farmers of Medak district were also found to have used labour efficiently in supermarket supply. 
The cost of cultivation of supermarket supply brinjal small farmers in Rangareddy district was Rs. 38473 which was comparatively less than traditional market supply farmers of Rs. 39902. Among the various items in operational cost of brinjal cultivation in Medak district, human labour accounts slightly $1 \%$ more for supermarket supply farms than traditional markets supply. It was also noted that human labour utilization of supermarket supply brinjal was more than tomato crop, this might be due to the long duration of brinjal crop. The expenditure on manures and fertilizers was highest in small farms followed by large farms for both the channel farmers. It was observed that the expenditure on plant protection chemicals was higher in brinjal compared to tomato, as more number of pests and diseases are observed on brinjal. Supermarket supply small farmers invested less amount on plant protection chemicals when compared to the traditional markets supply channels by Rs. 121 (Table 2). The reason may be that the supermarket suppliers are more conscious about chemicals usage than traditional farmers.

The cost of cultivation of supermarket supply bhendi large farmers in Rangareedy district was Rs. 29579 which was comparatively lower than supermarket supply small farms i.e Rs. 36313. The same trend was noticed in Medak district also. The cost of cultivation per hectare for supermarket supply bhendi small farmers in Rangareddy was Rs. 36314 which was comparatively less than traditional market supply farmers of Rs. 38969. In Medak district the cost of cultivation of supermarket supply bhendi small farmers was less than traditional market supply channels by Rs. 2170. Likewise, in tomato and brinjal, there is an inverse relationship between cost and farm size, the results revealed that supermarket farmer was efficient in carrying out the various operational activities. The total operational cost is observed to be more in bhendi compared to brinjal and tomato in both the districts. Among the various operational costs human labour utilization was more in bhendi compared to other vegetables which occupied a major share because of risk involved to carry out the cultural operations within the crop, followed by manures and fertilizers for both the channel farmers.

From the above analysis it was evident that the total cost of cultivation per hectare was highest in Rangareddy district brinjal traditional farmer followed by tomato and bhendi farmers. This difference across the vegetables was due to duration of the crops and the requirement of inputs. The difference across the channels was due to the lack of proper knowledge about the material inputs management. Small farmers were incurring more expenditure compared to large farmers in the cultivation of all these selected vegetables inspite of this small holders were gradually diversifying out of staples towards high-value commodities, (Birthal, Joshi and Gulati 2003) and this was expected as small holders had a higher endowment of labour in relation to land and thus, had a comparative advantage in production of labour-intensive high value crops (Birthal and Joshi 2007). 


\section{Cost concepts and income measures}

The comparison of cost concepts in table 4 revealed interesting findings in all the three selected vegetables. Cost $_{1}$ for tomato of supermarket supplier pertaining to small farms in Rangareddy district was less than the traditional market supply farms by Rs. 2,813.85. Cost $\mathrm{A}_{1}$ indicated an inverse relationship with farm size in tomato, brinjal, bhendi cultivation. This was mainly due to participation of more of owned labour in small farms. The $\mathrm{CostB}_{1}$ on tomato supermarket small farmers accounted to Rs. 15,008.08 against Rs. 17,029.17 of brinjal and Rs. 16794.23 of bhendi small farmers. While in Medak district tomato, brinjal and bhendi crop small farmers recorded Rs. 15,312.31, Rs. 16,258.75, Rs. 17,277.69 respectively. CostC ${ }_{1}$ has showed an inverse relationship with the farm size for both the market channels in two districts. Cost $\mathrm{C}_{3}$ which was $10 \%$ of Cost $\mathrm{C}_{2}$ indicated as Rs. 3638, Rs. 3847, and Rs. 3631 in Rangareddy district pertaining to supermarket suppliers of small farms with respect to tomato, brinjal and bhendi. In Medak district Cost $\mathrm{C}_{3}$ for supermarket supply small farms of tomato, brinjal, bhendi was indicated as Rs. 3598, 3762 and 3643 respectively.

The average yield of Rangareddy supermarket supplying small farms in case of tomato, brinjal, bhendi was 131, 132 and 68 quintal per hectare, while that of traditional market supply farmer's average yield for the selected vegetables was 130 , 134 and 67 quintal per hectare. In Rangareddy district supermarket supply tomato small farmer yield obtained was 131 quintals per hectare which was slightly higher than traditional market supply farmers of 130 quintals per hectare, in Medak district also supermarket supply farmers yields were slightly higher than traditional market supply farmers. It was also known that the average yields in quintals per hectare of all the three vegetables were slightly higher in Medak district pertaining to suppliers of supermarket small farms when compared to large farms which indicated an inverse relationship with farm size. It was observed that the gross returns (94098), farm business income (73518), family labour income (57401) obtained in Rupees per hectare were the highest in Rangareddy district brinjal producing supermarket supply small farmers than large farmers. for all the three selected vegetables the gross returns, farm business income, family labour income were highest in supermarket supply small farms than large farms. The reason was identified as more concentration paid by the small farmers in vegetable production which resulted higher yields and returns. Naveen et al., (2005) revealed that Supermarket channel farmers had adopted more capital intensive production technologies (irrigation interventions and enhanced use of soil fertility inputs) which resulted in their average land and labour productivity being 60-70 percentages higher than those of traditional channel farmers.

Different measures of return namely, gross income, net income, family labour income, farm family investment income and farm business income per hectare also revealed high degree of profit from supermarket supplying farms. It was found 
that retail chains had enhanced the farmers profitability by $10-15 \%$ (Changappa and Nagaraj 2005). Even though, the yields were slightly higher for supermarket supply farmers, a deeper view indicated that there was minimum difference in productivity of the three selected vegetables between the supermarket and traditional market supply farmers. But there were differences in cost of cultivation of the three selected vegetables between supermarket and traditional market supply farmers. The price received per quintal for supermarket supply farmers was relatively higher than traditional market supply farmers in both the districts for all the three selected vegetables due to the freshness retained and less damage caused by transportation for supermarket supply farmers (Tables 4, 5 and 6). Linking of traditional market farmers with retail outlets would enable small farmers to have more profit (Mangala and Changappa 2008).

\section{Discriminating characteristics between supermarket and traditional market supply farmers.}

The results of discriminant function analysis as studied between two distinct groups of farmers in the selected districts are presented in (Table 7). The $\mathrm{D}^{2}$ value was found to be 65.60 and 44.29 in Rangareddy and Medak districts, respectively which were statistically significant at one per cent level of probability indicating that the variables considered in the function are significantly distinguishing between the two groups of farmers.

The relative importance of the discriminators as seen through the table revealed that price, manures and fertilizers, yield, hired labour and net income contributed mostly to discriminate between two groups in Rangareddy, while in case of Medak district, transportation cost, rent for owned land, human labour, price received per quintal contributed mostly to discriminate between the two groups. This indicated that there was a significant difference in the cultivation of vegetables by the supermarket and traditional supply farmers.

\section{CONCLUSIONS}

This paper analyzed issue of small holder participation in high-value vegetable production and their access to the markets. Even though, the yields were slightly higher for supermarket supply farmers, a deeper view indicated that there was minimum difference in productivity of the three selected vegetables between the supermarket and traditional market supply farmers. But there were differences in cost of cultivation of the three selected vegetables between supermarket and traditional market supply farmers. It emerged from this study that small holders, despite their limited access to land, participated more in vegetable production and made sizeable contribution to their output. Further, small holders had greater endowment of family labour and were more efficient in production of labour intensive crops like vegetables. So it could be concluded that the supermarket supply farmers were profitable, as the collection centre officers and the distribution centre officers were 
disseminating good agricultural practices to the farmers who were linked with the supermarkets, hence led to reduced cost of cultivation. The profitability of small farmers could be increased by reducing the cost of cultivation, by adopting a location specific suitable method of input supply system. The linkage of supermarket with farming changed the method of farming especially for small farmers, through their intensive cultivation, and they had been able to earn considerably higher income. Developmental programs should assist small holder farmers to access the supermarket chain and would have to make sure that farmers meet the major portion of supermarket requirements. Production of most of the high -value vegetables is capital- and information/knowledge- intensive and riskier, while smallholders lack access to capital, improved technologies, quality inputs, extension services needed for entry into the high- value segment. Institutions like cooperatives, contract farming and growers associations were considered to improve producer's access to markets and the evidence indicated that these institutional innovations enhanced their access to market, quality inputs, improved technology information and services. It was, therefore, essential to strengthen institutional mechanisms that improve smallholders' access to credit, technology and support services. Institutional innovations that linked production with markets, enable producers cope up with risks, contributed towards development of efficient markets and extension systems, and reduced burden on public exchequer of providing such services. Task force on promotion of new and competitive agricultural market in private and cooperative sectors was required to encourage direct marketing and contract marketing programmes that facilitated industries and large trading companies to undertake procurement of agricultural commodities directly from the farmers field and to establish effective linkages between the farm production and retail chains. Reduction in commission charges, provision of cheap and efficient transport facilities, establishment of regulated markets, strengthening of the cooperative marketing institutions, innovations in packing and storage technology for the vegetables needed be developed. India being the land of small and marginal farmers and have been advocating the fact that small farmers are going to feed India, it is important to mobilize and help them to diversify to meet the increasing domestic demand of horticulture products. As identified from African nations the small farmers are the key to initiate the horticultural revolution and with technical change and increase in international competitiveness large scale operations and vertical integration takes place. Thus to sustain the growth and development of the small land holder, farmers should be monitored to identify, select and support horticultural and entrepreneurial smallholders. Linking small farmers with high value urban and export markets would lead to the development of the rural sector. 


\section{REFERENCES}

Alam, G. and Verma, D. 2007. Connecting small-scale farmers with dynamic markets: A case study of a successful supply chain in Uttarakhand. Centre for Sustainable Development, Dehradun, India.

Birthal, P. S., Joshi, P. K. and Gulati, A. 2003. Vertical coordination in high value food commodities: Implications for small holders. MTID discussion paper No. 85.

Birthal, P. S. and Joshi, P. K. 2007. Institutional innovations for improving small holder participation in high value agriculture: A case of fruit and vegetable grower's association in India. Quarterly journal of International Agriculture., 46 (1): 49-66.

Chengappa, P. G. and Nagaraj, N.2005. Marketing of major fruits and vegetables in and around Bangalore report Department of Agricultural economics, University of Agricultural Sciences, Bangalore.

David, B. Spencer, H. and Weatherspoon, D. 2003. Supermarket procurement practice in developing countries: Redefining the role of the public and private sectors. American Journal of Agricultural Economics., 85 (5): 1147-1154.

Dhananjaya, B.N. and Rao, A. U. 2009. Namdhari Fresh Limited in M. Harper 2009: Inclusive Value chains in India: Linking the Smallest Producers to Modern Markets, World Scientific, Singapore, Cast study 1, Chapter 3, 26-41.

Joseph, M., Soundararajan, N., Gupta, M. and Sahu, S. (2008). Impact of Organized Retailing on the Unorganized Sector. Indian Council for Research on International Economic Relations (ICRIER), New Delhi.

Joshi, P. K. Tiwari, L. and Birthal, P. S. 2006. Diversification and its impact on small holders: Evidence from a study on vegetable production. Agricultural Economics Research Review., 19(2): 219-236.

Mangala, K. P. and Chengappa, P. G. 2008. A novel Agribusiness model for backward linkages with farmers A case of food retail chain. Agricultural Economics Research Review., 21(conference special): 363-370.

Naveen, D., Reardon, T., Chega, J., Odera, M. M., Weatherspoon, D., Ondieki, M., Waura, F. and Kenyatta, J. 2005. The rapid rise of supermarkets in Kenya Impact on the fresh fruits and vegetables supply system. Electronic Journal of Agricultural and development Economics., 1(2): 168-183.

Singh, S. 2010. Understanding Practice of Contract Farming in India: A Small Producer Perspective. On-line Resource Book, National Centre for Agricultural Economics and Policy Research, New Delhi.

Sulaiman, R., Kalaivani, N.J. and Handoo, Jitendar. 2010. Organized Retailing of Fresh Fruits and Vegetables: Is it really helping producers. CRISP Working Paper 2010-001. Centre for Research on Innovation and Science Policy, Hyderabad. 
Table 1: Cost of cultivation of tomato supermarket and traditional market supply farmers in Ranga reddy and Medak districts of Andhra Pradesh.

(Rupees per hectare)

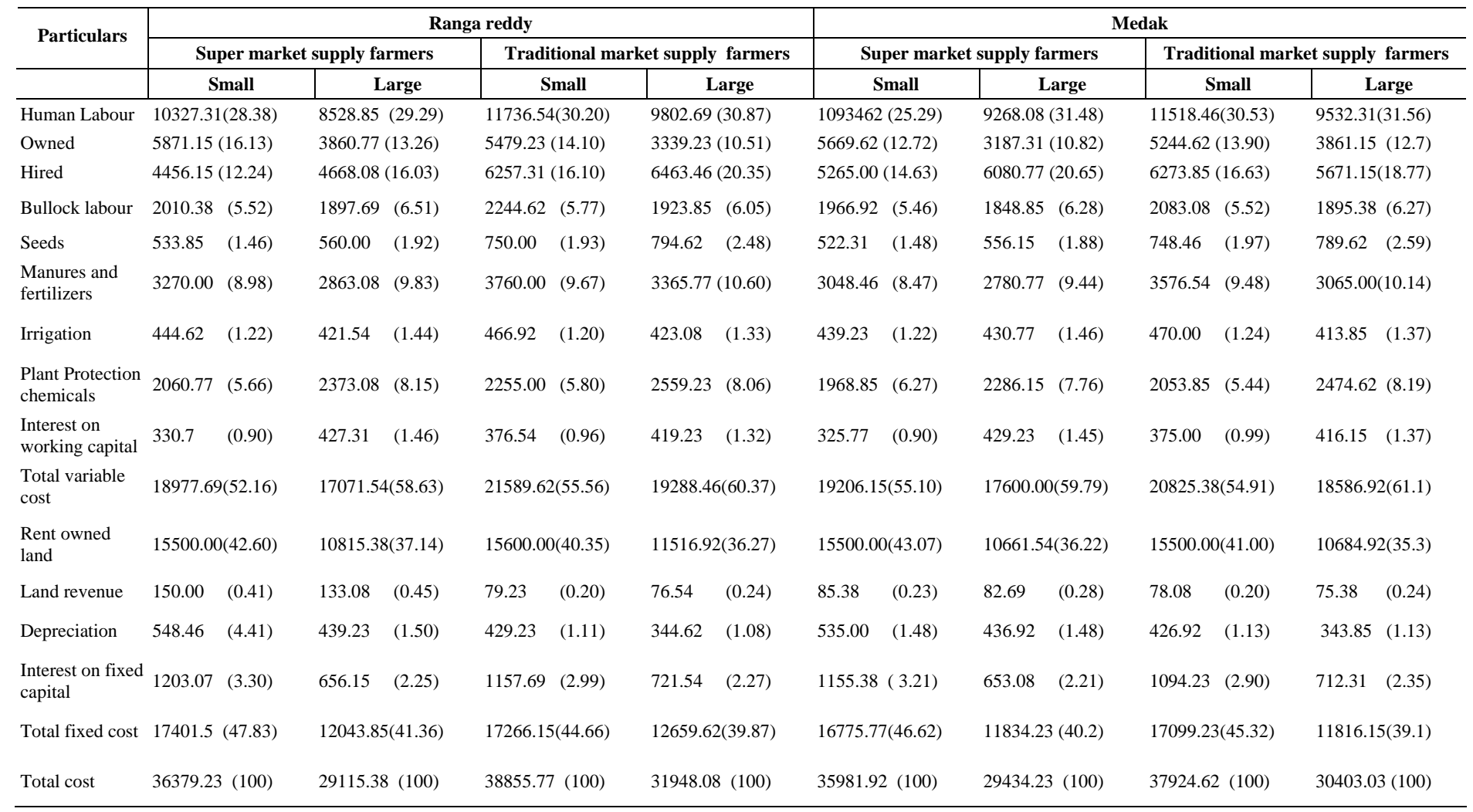

figures in parenthesis indicate percentages to total cost 
Table 2: Cost of cultivation of brinjal supermarket and traditional market supply farmers in Ranga reddy and Medak districts of Andhra Pradesh. (Rupees per hectare)

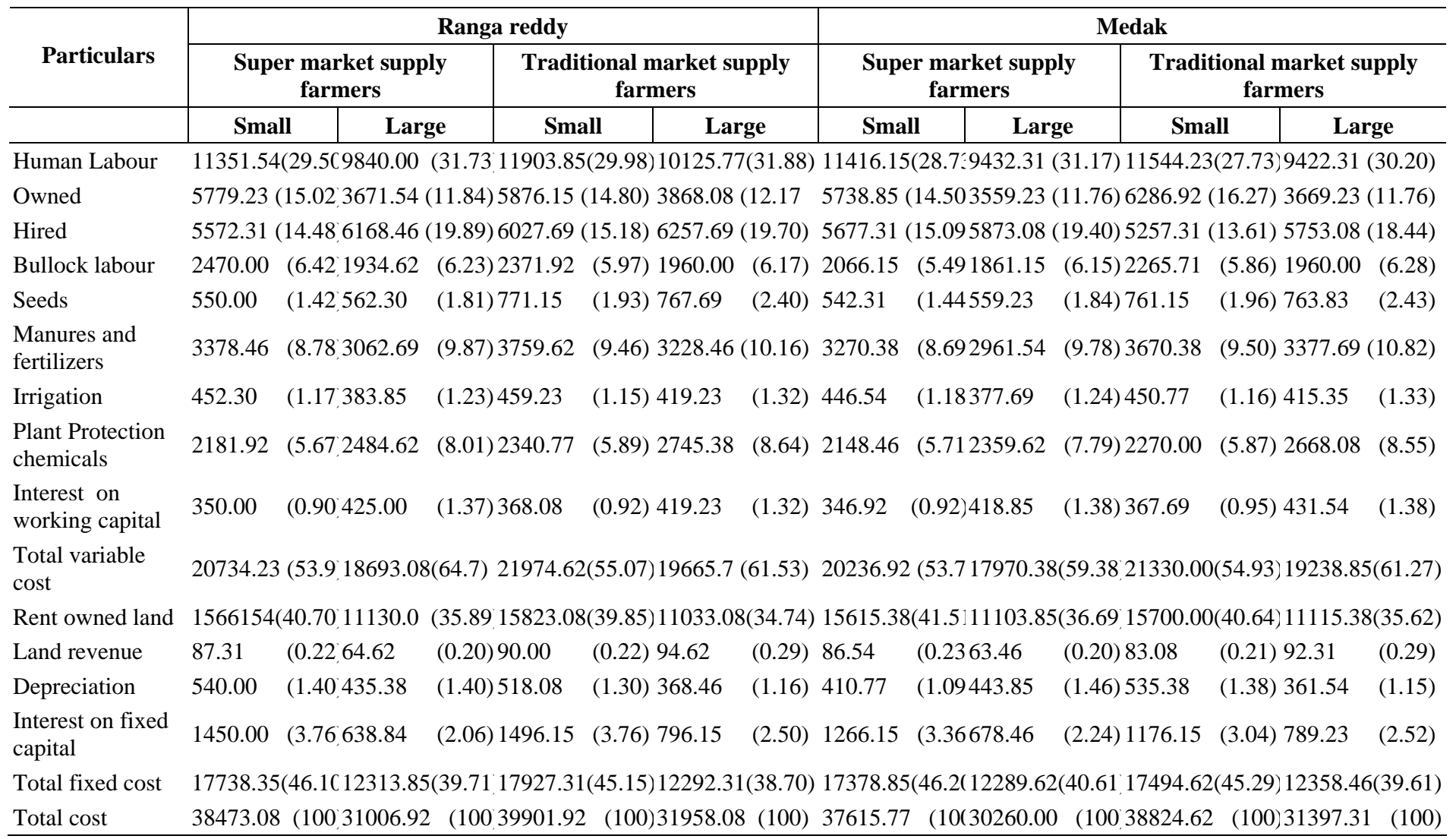

(figures in parenthesis indicate percentages to total cost) 
Table 3: Cost of cultivation of bhendi supermarket and traditional market supply farmers in Ranga reddy and Medak districts of Andhra Pradesh.

(Rupees per hectare)

\begin{tabular}{|c|c|c|c|c|c|c|c|c|}
\hline \multirow{3}{*}{ Particulars } & \multicolumn{4}{|c|}{ Ranga reddy } & \multicolumn{4}{|c|}{ Medak } \\
\hline & \multicolumn{2}{|c|}{ Super market supply farmers } & \multicolumn{2}{|c|}{$\begin{array}{c}\text { Traditional market supply } \\
\text { farmers }\end{array}$} & \multicolumn{2}{|c|}{ Super market supply farmers } & \multicolumn{2}{|c|}{$\begin{array}{c}\text { Traditional market supply } \\
\text { farmer }\end{array}$} \\
\hline & Small & Large & Small & Large & Small & Large & Small & Large \\
\hline Owned & $6444.23(17.74)$ & $3735.38(12.62)$ & $6553.85(16.90)$ & 4279.23 (13.95) & $6428.08(17.64)$ & $3664.23(12.61)$ & $6538.85(17.02)$ & 4279.23 (13.95) \\
\hline Hired & $4674.62(12.87)$ & $6057.31(20.47)$ & $5574.23(14.37)$ & $5970.00(19.47)$ & $5630.77(15.45)$ & $5962.31(20.52)$ & $5856.92(15.24)$ & $5970.00(19.47)$ \\
\hline Bullock labour & 2655.77 (7.31) & 2423.08 (8.19) & $2723.85(7.02)$ & 2587.69 (8.44) & $2423.08(6.65)$ & $2260.00 \quad(7.78)$ & $2671.54 \quad(6.95)$ & 2587.69 (8.44) \\
\hline $\begin{array}{l}\text { Manures and } \\
\text { fertilizers }\end{array}$ & $3864.62(10.64)$ & $3474.23(11.74)$ & $4073.85(10.50)$ & 3672.69 (11.98) & $3762.3(10.32)$ & $3580.38(12.32)$ & $3957.31(10 . .30)$ & 3672.69 (11.98) \\
\hline Irrigation & $455.38 \quad(1.25)$ & $260.00 \quad(0.87)$ & $485.38 \quad(1.25)$ & $205.38 \quad(0.66)$ & $449.23 \quad(1.23)$ & $260.00 \quad(0.89)$ & 478.46 & $205.38 \quad(0.66)$ \\
\hline $\begin{array}{l}\text { Plant protection } \\
\text { chemicals }\end{array}$ & 2686.15 (7.39) & 2389.62 (8.07) & $2731.92 \quad(7.04)$ & $17.69(7.88)$ & $.77(7.05)$ & $62(8.22)$ & 2656.92 & 2417.69 (7.88) \\
\hline $\begin{array}{l}\text { Interest on working } \\
\text { capital }\end{array}$ & $318.85 \quad(0.87)$ & $322.31 \quad(1.08)$ & $336.15 \quad(0.86)$ & $316.92 \quad(1.03)$ & $315.77 \quad(0.86)$ & 313.85 & 321.54 & 316.92 \\
\hline Depreciation & $463.85 \quad(1.27)$ & $332.31 \quad(1.12)$ & $466.92 \quad(1.20)$ & $363.85 \quad(1.18)$ & $460.00 \quad(1.26)$ & 350.00 & 465.00 & $363.85 \quad(1.18)$ \\
\hline $\begin{array}{l}\text { Interest on fixed } \\
\text { capital }\end{array}$ & $987.69 \quad(2.71)$ & $784.62 \quad(2.65)$ & 957.69 & $886.15 \quad$ (2.89) & $975.38 \quad(2.67)$ & 791.92 & 952.69 & $886.15 \quad$ (2.89) \\
\hline Total fixed cost & $14586.92(40.16)$ & $10400.77(35.16)$ & $15644.62(40.35)$ & 10653.85(34.75) & $14229.23(39.05)$ & 10104.62(34.78) & 15284.62(39.79) & $10653.85(34.75)$ \\
\hline Total cost & 36313.85 (100) & $29579.23 \quad(100)$ & 38969.23 (100) & $30855.00 \quad(100)$ & $36436.54(100)$ & $29045.38 \quad(100)$ & 38606.15 (100) & $30855.00 \quad(100)$ \\
\hline
\end{tabular}

(Figures in parenthesis indicate percentages to total cost) 
Table 4. Market wise Comparision of cost concepts of selected vegetables production in Rangareddy and Medak districts of Andhra Pradesh For the year 2009-2010.

\begin{tabular}{|c|c|c|c|c|c|c|c|c|}
\hline \multirow{3}{*}{$\begin{array}{l}\text { Particulars } \\
\text { Tomato }\end{array}$} & \multicolumn{4}{|c|}{ Rangareddy } & \multicolumn{4}{|c|}{ Medak } \\
\hline & \multicolumn{2}{|c|}{ Super market supply farmers } & \multicolumn{2}{|c|}{ Traditional farmers } & \multicolumn{2}{|c|}{ Super market supply farers } & \multicolumn{2}{|c|}{ Traditional farmers } \\
\hline & Small & Large & Small & Large & Small & Large & Small & Large \\
\hline Cost $A_{1}$ & 13805.00 & 13783.08 & 16618.85 & 16170.38 & 14156.92 & 14932.31 & 16085.77 & 14945.00 \\
\hline Cost $\mathrm{A}_{2}$ & 18805.00 & 16783.08 & 21618.85 & 20170.38 & 19156.90 & 19932.31 & 21085.76 & 19945.00 \\
\hline Cost $\mathrm{B}_{1}$ & 15008.08 & 14439.23 & 17776.54 & 16891.92 & 15312.31 & 15585.38 & 17180.00 & 15657.31 \\
\hline Cost $\mathrm{B}_{2}$ & 35508.08 & 28254.62 & 38376.54 & 33408.84 & 35312.32 & 31246.92 & 37680.00 & 31341.92 \\
\hline Cost $C_{1}$ & 20879.23 & 19260.00 & 23255.77 & 20231.15 & 20981.92 & 18772.69 & 22424.62 & 19518.46 \\
\hline Cost $C_{2}$ & 36379.23 & 29115.38 & 38855.77 & 31948.08 & 35981.94 & 29434.23 & 37924.62 & 30403.03 \\
\hline Cost $C_{3}$ & 3637.92 & 3007.53 & 3885.57 & 3174.80 & 3598.19 & 3443.42 & 3792.46 & 3020.30 \\
\hline \multicolumn{9}{|l|}{ Brinjal } \\
\hline Cost $A_{1}$ & 15579.16 & 15521.54 & 16706.54 & 16260.77 & 14993.75 & 14918.46 & 15661.54 & 15823.46 \\
\hline Cost $\mathrm{A}_{2}$ & 20579.17 & 19421.52 & 21706.55 & 20060.77 & 18993.72 & 18418.42 & 20661.52 & 18823.44 \\
\hline Cost $\mathrm{B}_{1}$ & 17029.17 & 16205.38 & 18202.69 & 17056.92 & 16258.75 & 15596.92 & 16837.69 & 16612.69 \\
\hline Cost $B_{2}$ & 36695.83 & 31335.38 & 39025.77 & 31890.00 & 35875.42 & 30200.77 & 37537.63 & 30728.08 \\
\hline Cost $C_{1}$ & 22809.17 & 19876.92 & 24078.85 & 20925.00 & 22005.00 & 19156.15 & 23124.62 & 20281.92 \\
\hline Cost $C_{2}$ & 38473.08 & 31006.92 & 39901.92 & 31958.08 & 37615.77 & 30260.00 & 38824.62 & 31397.31 \\
\hline Cost $C_{3}$ & 3847.58 & 3100.69 & 3990.19 & 3195.80 & 3762.16 & 2976.00 & 3882.46 & 3129.73 \\
\hline \multicolumn{9}{|l|}{ Bhendi } \\
\hline Cost $A_{1}$ & 15806.54 & 15839.23 & 17306.15 & 16349.62 & 16302.31 & 15689.23 & 17314.62 & 16332.31 \\
\hline Cost $A_{2}$ & 20806.35 & 20839.23 & 22306.14 & 21349.63 & 21302.21 & 19687.22 & 22314.64 & 20332.33 \\
\hline Cost $\mathrm{B}_{1}$ & 16794.23 & 16623.85 & 18263.85 & 17235.77 & 17277.69 & 16481.15 & 18267.31 & 17189.25 \\
\hline Cost $\mathrm{B}_{2}$ & 34869.62 & 30843.85 & 37415.38 & 31575.77 & 35008.46 & 29381.17 & 37067.34 & 30439.23 \\
\hline Cost $C_{1}$ & 23238.46 & 20359.23 & 24817.69 & 21515.00 & 23705.77 & 20145.38 & 24806.15 & 21540.00 \\
\hline Cost $C_{2}$ & 36313.85 & 29579.23 & 38969.23 & 30855.00 & 36436.54 & 29045.38 & 38606.17 & 30855.00 \\
\hline Cost $C_{3}$ & 3631.38 & 2957.92 & 3896.92 & 3085.50 & 3643.65 & 2904.53 & 3860.61 & 3079.00 \\
\hline
\end{tabular}


Table 5 : Market wise farm income measures for tomato and brinjal production in Rangareddy and Medak districts of Andhra Pradesh

(Rupees per hectare)

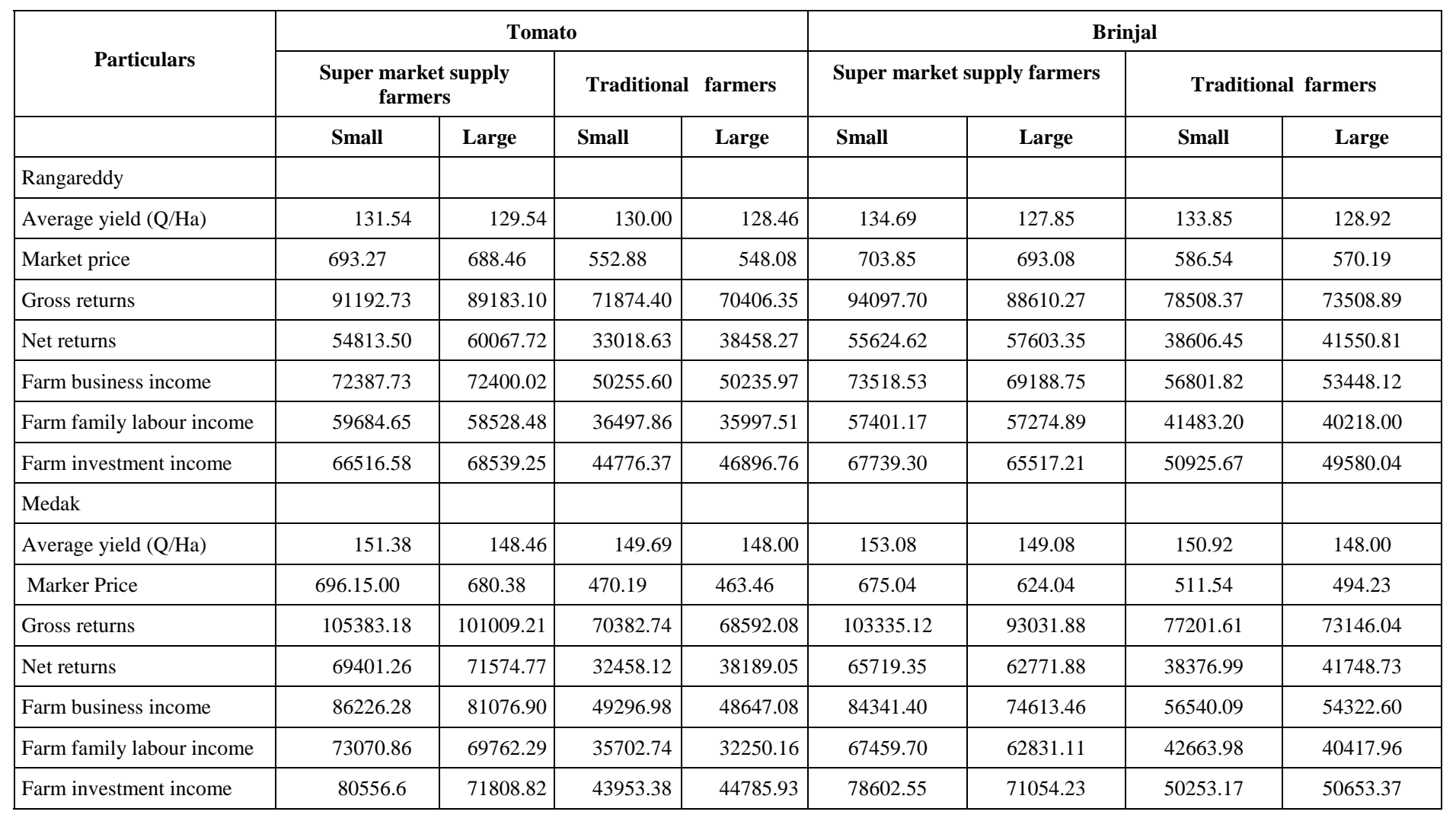


Table 6 : Market wise farm income measures for bhendi production in Rangareddy and Medak districts of Andhra pradesh

(Rupees per hectare)

\begin{tabular}{|l|c|c|c|c|}
\hline \multicolumn{1}{|c|}{ Particulars } & \multicolumn{3}{c|}{ Bhendi } \\
\hline & Super market supply farmers & \multicolumn{2}{c|}{ Traditional farmers } \\
\hline Rangareddy & Small & Large & & \\
\hline Average yield (Q/Ha) & & & 67.38 & 65.85 \\
\hline Market Price & 69.15 & 66.92 & 1148.08 & 1131.73 \\
\hline Gross returns & 1269.23 & 1228.85 & 77357.63 & 74524.42 \\
\hline Net returns & 86498.02 & 82234.64 & 38388.40 & 43669.42 \\
\hline Farm business income & 50184.17 & 52655.41 & 55051.49 & 53174.79 \\
\hline Farm family labour income & 65691.67 & 61395.41 & 42942.27 & 40948.65 \\
\hline Farm investment income & 51628.40 & 51390.79 & 48497.64 & 48895.56 \\
\hline Medak & 59247.44 & 57660.03 & & \\
\hline Average yield (Q/Ha) & & & 72.77 & 69.69 \\
\hline Market Price & 73.85 & 71.69 & 1059.62 & 1054.81 \\
\hline Gross returns & 1168.27 & 1155.77 & 77108.54 & 73509.70 \\
\hline Net returns & 85907.48 & 82857.15 & 38502.39 & 42719.70 \\
\hline Farm business income & 49470.94 & 53811.77 & 54793.90 & 53177.37 \\
\hline Farm family labour income & 64605.27 & 63169.93 & 43041.20 & 41070.47 \\
\hline Farm investment income & 53899.02 & 50475.98 & 48255.05 & 48826.60 \\
\hline
\end{tabular}


Table 7 : Discriminant function analysis for vegetable cultivators in Rangareddy and Medak districts of Andhra Pradesh.

\begin{tabular}{|c|c|c|c|c|c|}
\hline \multirow{2}{*}{ S.No } & \multirow{2}{*}{\begin{tabular}{|l|} 
Districts \\
Variables
\end{tabular}} & \multicolumn{2}{|c|}{ Rangareddy } & \multicolumn{2}{|c|}{ Medak } \\
\hline & & $\begin{array}{c}\text { Discriminant } \\
\text { coefficients }\end{array}$ & t-value & $\begin{array}{c}\text { Discriminant } \\
\text { coefficients }\end{array}$ & t-value \\
\hline 2 & Owned labour & $0.00016^{* *}$ & 2.668 & $0.00048^{* * *}$ & 4.781 \\
\hline 3 & Hired labour & $0.00055^{* * *}$ & 6.260 & $0.00050 * * *$ & 4.691 \\
\hline 4 & Bullock labour & $0.00059 *$ & 2.579 & $0.00117 * *$ & 2.605 \\
\hline 6 & Manures and fertilizers & $0.00162 * * *$ & 8.039 & $0.0005^{* *}$ & 3.067 \\
\hline 7 & Irrigation & -0.00064 & 0.867 & $-0.00180 * *$ & 3.010 \\
\hline 8 & Plant protection chemicals & $0.00046^{*}$ & 2.286 & 0.00023 & 0.953 \\
\hline 9 & Rent for own land & $-0.00020 * * *$ & 4.193 & $0.00018 * * *$ & 4.880 \\
\hline 10 & Depreciation & $-0.00101^{*}$ & 2.230 & $0.00127 *$ & 2.114 \\
\hline 14 & Distance covered & $0.01962 * * *$ & 2.767 & -0.00818 & 1.192 \\
\hline \multirow[t]{5}{*}{15} & Transportation cost & 0.00560 & 1.819 & $0.01856 * * *$ & 5.205 \\
\hline & Misclassification probability & \multicolumn{2}{|c|}{$0.0051 \%$} & \multicolumn{2}{|c|}{$0.0875 \%$} \\
\hline & $\mathrm{D}^{2}$ & \multicolumn{2}{|c|}{65.60} & \multicolumn{2}{|c|}{44.29} \\
\hline & $\mathrm{T}^{2}$ & \multicolumn{2}{|c|}{3838.80} & \multicolumn{2}{|c|}{2591.84} \\
\hline & F statistics & \multicolumn{2}{|c|}{210.24} & \multicolumn{2}{|c|}{141.94} \\
\hline
\end{tabular}

*** Significant at one percent level $\quad * *$ Significant at five percent level $\quad *$ Significant at ten percent level 